\title{
Metode Identifikasi Rhodamine B pada Makanan dan Kosmetik
}

\author{
Dwi Mega Permatahati ${ }^{1(\mathrm{CA})}$, Luh Pratiwi Diva Yanti ${ }^{2}$ \\ 1(CA) Program Studi Farmasi, Fakultas Matematika dan Ilmu Pengetahuan Alam, Universitas Udayana, \\ Indonesia; dmpermatahati@gmail.com (Corresponding Author) \\ ${ }^{2}$ Program Studi Farmasi, Fakultas Matematika dan Ilmu Pengetahuan Alam, Universitas Udayana, \\ Indonesia
}

\begin{abstract}
Rhodamine B is a synthetic dye used in the textile and paper industries. This substance is defined as substance that is prohibited in food through the Regulation of Minister of Health No. 239/Menkes/Per/V/85. The use of these dyes if consumed in the long term can lead to impaired liver function and cancer. Based on the problems above, it is necessary to conduct qualitative and quantitative analysis to identify Rhodamine B in food and cosmetics. Several methods have been developed and applied to identify the content of Rhodamine B using different analytical techniques. The most widely used method for analyzing Rhodamine content is the spectrophotometric method then HPLC and other methods
\end{abstract}

Keywords: Rhodamine B; Food; Analysis

\begin{abstract}
ABSTRAK
Rhodamin B adalah salah satu pewarna sintetis yang biasa digunakan pada industri tekstil dan kertas. Zat ini ditetapkan sebagai zat yang dilarang penggunaannya pada makanan melalui Peraturan Menteri Kesehatan (Permenkes) No.239/Menkes/Per/V/85. Penggunaan pewarna tersebut jika dikonsumsi dalam jangka waktu yang lama dapat mengakibatkan gangguan fungsi hati maupun kanker. Berdasarkan permasalahan di atas maka perlu dilakukan analisis kualitatif dan kuantitatif untuk mengidentifikasi Rhodamin B pada makanan dan kosmetik. Beberapa metode telah dikembangkan dan diterapkan untuk mengidentifikasi kandungan Rhodamin B dengan menggunakan teknik analisis yang berbeda. Metode yang paling banyak digunakan untuk analisis kandungan Rhodamin yaitu metode spektrofotomerti kemudian HPLC dan metode-metode lainnya
\end{abstract}

Kata Kunci : Rhodamin B; Makanan; Analisis

\section{PENDAHULUAN}

Pangan merupakan kebutuhan primer manusia yang diharapkan tersedia cukup, aman, dan bergizi untuk dikonsumsi. Menurut Peraturan Kepala BPOM No. 36 tahun 2013, pangan adalah segala sesuatu yang berasal dari sumber hayati, baik yang diolah maupun tidak diolah yang diperuntukkan sebagai bahan makanan atau minuman bagi konsumsi manusia, termasuk bahan tambahan pangan dan bahan baku pangan (BPOM RI, 2013). Bahan tambahan pangan adalah bahan yang ditambahkan dalam pangan untuk memengaruhi sifat atau bentuk pangan. Bahan tambahan pangan telah diatur dalam Peraturan BPOM 
No.11 tahun 2009 yang memuat bahan tambahan pangan yang telah diijinkan serta dilarang beserta batasan-batasannya.

Salah satu bahan tambahan pangan yang dilarang penggunaannya adalah Rhodamin B. Rhodamin adalah keluarga senyawa kimia terkait, pewarna floron seperti Rhodamine 6G, Rhodamine B dan lainnya (Duran et al., 2011) . Pemerintah Indonesia melalui Peraturan Menteri Kesehatan (Permenkes) No. 239/Menkes/Per/V/1985 menetapkan 30 zat pewarna berbahaya. Rhodamin B adalah zat warna dari golongan pewarna kationik (cationic dyes) yang dilarang penggunaanya di Indonesia (BPOM RI, 2011). Dimana, hal tersebut telah diatur pada Peraturan Kepala Badan Pengawas Obat Dan Makanan Republik Indonesia Nomor Hk.03.1.23.08.11.07331 Tahun 2011 Tentang Metode Analisis Kosmetika. Aturan tersebut telah ditegakkan sejak lama karenaefek dari Rhodamin B yang sangat berbahaya bagi kesehatan dan menyebabkan gangguan fungsi hati apabila terpapar dalam jangka waktu yang panjang. Selain itu, International Agency for Research on Cancer (IARC) juga mengelompokkan senyawa Rhodamin B sebagai pemicukanker kategori 3 (BPOM RI, 2008). Rhodamin B umumnya digunakan sebagai zat warna untuk tekstil (sutra,wool, kapas), cat, kertas atau pakaian (Afriyeni dan Utari, 2016; BPOM RI, 2008)

Rhodamin B merupakan pewarna sintetis berbentuk serbuk kristal, berwarna hijau atau ungu kemerahan, tidak berbau, dan dalam larutan akan berwarna merah terang berpendar atau berfluorosensi (BPOM, 2014). Rhodamin B memiliki nama lain tetraetil rhodamin, $D$ and C Red No.19, ADC Rhodamine B, Aizen Rhodamine, Brilliant Pink, dan merah K10 (BPOM, 2014; BPOM, 2008) dengan rumus molekul $\mathrm{C}_{28} \mathrm{H}_{31} \mathrm{C}_{1} \mathrm{~N}_{2} \mathrm{O}_{3}$ dan berat molekul sebesar 479,01 g/mol. Rhodamin $\mathrm{B}$ memiliki titik lebur $165^{\circ} \mathrm{C}$, titik leleh $270^{\circ} \mathrm{C}$, dan titik didih sebesar $310^{\circ} \mathrm{C}$. Rhodamin B bersifat larut dalam air alkohol, eter, benzena, sedikit larut dalam asam klorida dan natrium hidroksida serta tidak larut dalam pelarut oganik (Kemenkes RI, 2014). Berikut merupakan rumus molekul Rhodamin B

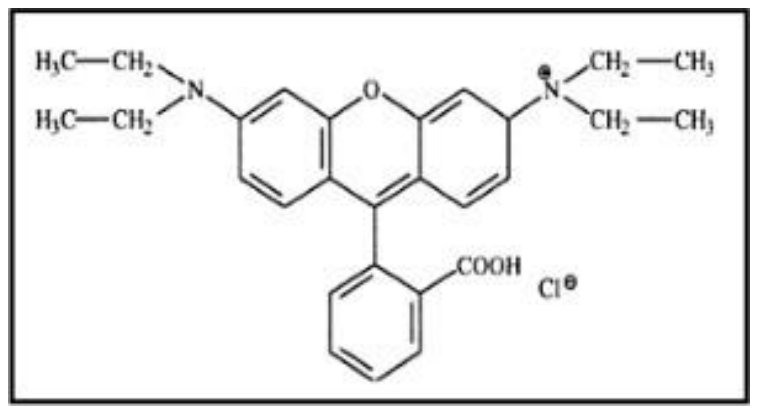

Gambar 1. Rumus molekul Rhodamin B

Menurut WHO (2000), Rhodamin B berbahaya bagi kesehatan manusia karena sifat kimianya dan kandungan logam berat. Rhodamin B mengandung senyawa klor $(\mathrm{Cl})$. Klorin adalah senyawa halogen yang berbahaya dan reaktif. Jika tertelan, maka senyawa ini akan berusaha keras untuk mencapai stabilitas dalam tubuh dengan mengikat senyawa lain di dalam tubuh, ini adalah racun bagi tubuh. Selain itu, Rhodamin B juga memiliki senyawa alkylating $\left(\mathrm{CH}_{3}-\mathrm{CH}_{3}\right)$ yang dapat mengikat protein, lemak, dan DNA dalam tubuh. 
Beberapa penelitian juga menyatakan bahwa Rhodamin B dalam jangka panjang dapat menumpuk di dalam tubuh dan dapat menyebabkan gejala pembesaran hati dan ginjal,disfungsi hati, kerusakan hati, gangguan fisiologis tubuh, atau bahkan dapat menyebabkan kanker hati (Wibowo dan Saebani, 2016). Dalam penelitian Mayori dkk. (2017), Rhodamin B mempengaruhi struktur histologis ginjal dari mencit dimana dosis dan lamanya pengobatan Rhodamin B memiliki pengaruh signifikan terhadap persentase kerusakan glomerulus, dan begitu pula interaksi kedua faktor tersebut. Analisis histologis menunjukkan adanya penyempitan ruang bowman di glomerulus, hipertrofi, nekrosis, dan serosis tubulus. Rhodamin B mengandung 13 ppm timbal (Pb) dan 1,4 ppm arsen (As) (Sun and Yang, 2017). Timbal yang tertelan akan beredar mengikuti aliran darah, diserap kembali oleh ginjal dan otak kemudian disimpan di dalam tulang dan gigi. Timbal yang tertimbun dalam darah dapat melewati sawar darah otak dan mengganggu metabolisme sel-sel saraf melalui penghambatan respirasi mitokondria sel saraf. Hambatan ini dapat menyebabkan gangguan pada hipofisis dan hipotalamus sehingga menyebabkan terganggunya sekresi hormon- hormon penting pada siklus ovarium yaitu FSH dan LH (Febrina dkk., 2017).

\section{METODE}

Referensi yang digunakan pada review artikel ini berasal dari jurnal-jurnal nasional maupun internasional. Kriteria jurnal yang digunakan pada review ini yaitu meliputi jurnal nasional dan internasional tentang metode identifikasi Rhodamin B pada makanan dan kosmetik selama 15 tahun terakhir (2006-2021).

\section{HASIL}

Tabel 1. Metode analisis Rhodamin B dalam beberapa sampel

\begin{tabular}{|c|c|c|c|c|}
\hline Sampel & Metode analisis & Detektor & $\begin{array}{c}\text { Panjang } \\
\text { gelombang/Ionisasi }\end{array}$ & Pustaka \\
\hline $\begin{array}{l}\text { Paprika, kentang } \\
\text { goreng, permen } \\
\text { karet ,pizza } \\
\text { pedas, nasi pedas }\end{array}$ & $\begin{array}{c}\text { Analisis } \\
\text { Spektrofotometri }\end{array}$ & UV-Vis & $\begin{array}{c}500-600 \mathrm{~nm}(\lambda \text { maks }= \\
576 \mathrm{~nm})\end{array}$ & $\begin{array}{l}\text { Alesso et al., } \\
\quad 2012\end{array}$ \\
\hline Saus & $\begin{array}{l}\text { Analisis kromatografi } \\
\text { kertas. Harga Rf } \\
\text { sampel dibandingkan } \\
\text { dengan harga Rf } \\
\text { warna pembanding, } \\
\text { jika diperoleh harga } \\
\text { Rf yang sama atau } \\
\text { mendekati zat warna } \\
\text { adalah jenis yang } \\
\text { sama yaitu rhodamin } \\
\text { b, kuning FCF, } \\
\text { eritrosin, amaran dan } \\
\text { ponceau 4R } \\
\text { (Cahyadi, 2009) }\end{array}$ & - & - & $\begin{array}{c}\text { Abdurrahmansya } \\
\text { h, dan Chrislia, } \\
2017\end{array}$ \\
\hline
\end{tabular}




\begin{tabular}{|c|c|c|c|c|}
\hline Sampel & Metode analisis & Detektor & $\begin{array}{c}\text { Panjang } \\
\text { gelombang/Ionisasi }\end{array}$ & Pustaka \\
\hline Terasi & $\begin{array}{c}\text { Analisis } \\
\text { Spektrofotometri }\end{array}$ & UV-Vis & $\begin{array}{c}500-600 \mathrm{~nm}(\lambda \mathrm{maks}= \\
538 \mathrm{~nm})\end{array}$ & $\begin{array}{c}\text { Amir dan } \\
\text { Mahdi, } 2017\end{array}$ \\
\hline Bubuk cabai & $\begin{array}{c}\text { Analisis } \\
\text { Spektrofotometri }\end{array}$ & Fluoresensi & & $\begin{array}{l}\text { Bakheet and } \\
\text { Zhu, } 2017\end{array}$ \\
\hline Permen & $\begin{array}{c}\text { Analisis } \\
\text { Spektrofotometri }\end{array}$ & UV-Vis & $\begin{array}{c}500-600 \mathrm{~nm}(\lambda \mathrm{maks}= \\
503 \mathrm{~nm})\end{array}$ & $\begin{array}{c}\text { Gresshma and } \\
\text { Paul, } 2012\end{array}$ \\
\hline Saus & $\begin{array}{c}\text { Analisis kualitatiff } \\
\text { dilaksanakan dengan } \\
\text { metodekonvensional } \\
\text { menggunakanbenang } \\
\text { wol. Hasil positif } \\
\text { ditandai dengan warna } \\
\text { merahpada benang } \\
\text { wol (yang } \\
\text { mengandung sampel) } \\
\text { tidak } \\
\text { dapat dicuci oleh air }\end{array}$ & - & - & $\begin{array}{l}\text { Laksmita } \\
\text { dkk., } 2018\end{array}$ \\
\hline Bubuk cabai & $\begin{array}{c}\text { Analisis } \\
\text { Spektrofotometri }\end{array}$ & UV-Vis & - & $\begin{array}{l}\text { Liu et al., } \\
\quad 2013\end{array}$ \\
\hline Paprika & UPLC & MS & ESI & Lu et al., 2012 \\
\hline Lipstik & $\begin{array}{c}\text { - Analisis kromatografi } \\
\text { kertas } \\
\text { - Analisis kromatografi } \\
\text { lapis tipis } \\
\end{array}$ & - & - & $\begin{array}{c}\text { Masyulani dan } \\
\text { Tristy, 2019; } \\
\text { Syamsyuri, } \\
2017 \\
\end{array}$ \\
\hline Kerupuk & $\begin{array}{c}\text { Analisis } \\
\text { Spektrofotometri }\end{array}$ & UV-Vis & $500-600 \mathrm{~nm}$ & $\begin{array}{l}\text { Sidabutar, et } \\
\text { al., } 2019\end{array}$ \\
\hline Softdrink & $\begin{array}{c}\text { Analisis } \\
\text { Spektrofotometri }\end{array}$ & UV-Vis & $\begin{array}{c}500-600 \mathrm{~nm}(\lambda \mathrm{maks}= \\
556 \mathrm{~nm})\end{array}$ & $\begin{array}{l}\text { Soylak et al., } \\
2011\end{array}$ \\
\hline Saus kedelai & HPLC & Fluoresensi & $500-600 \mathrm{~nm}$ & $\begin{array}{c}\text { Sun and Yang, } \\
2017\end{array}$ \\
\hline Minyak cabai & $\begin{array}{c}\text { Analisis } \\
\text { Spektrofotometri }\end{array}$ & $\mathrm{UV}$-Vis & $\begin{array}{l}\text { Panjang gelombang } \\
\text { eksitasi dan panjang } \\
\text { gelombang deteksi } \\
\text { masing-masing pada } \\
\text { 530/25 nm dan 590/35 } \\
\qquad \mathrm{nm} .\end{array}$ & $\begin{array}{l}\text { Wang et al., } \\
\quad 2017\end{array}$ \\
\hline Kue bolu & $\begin{array}{c}\text { Analisis } \\
\text { Spektrofotometri }\end{array}$ & $\mathrm{UV}$-Vis & UV-Vis & $\begin{array}{l}\text { Yamlean, } \\
2011\end{array}$ \\
\hline Sponge cake & HPLC & FID & Sponge cake & $\begin{array}{l}\text { Yantih dkk., } \\
2015\end{array}$ \\
\hline
\end{tabular}


Gambar 2. Diagram distribusi metode analisis Rhodamin B

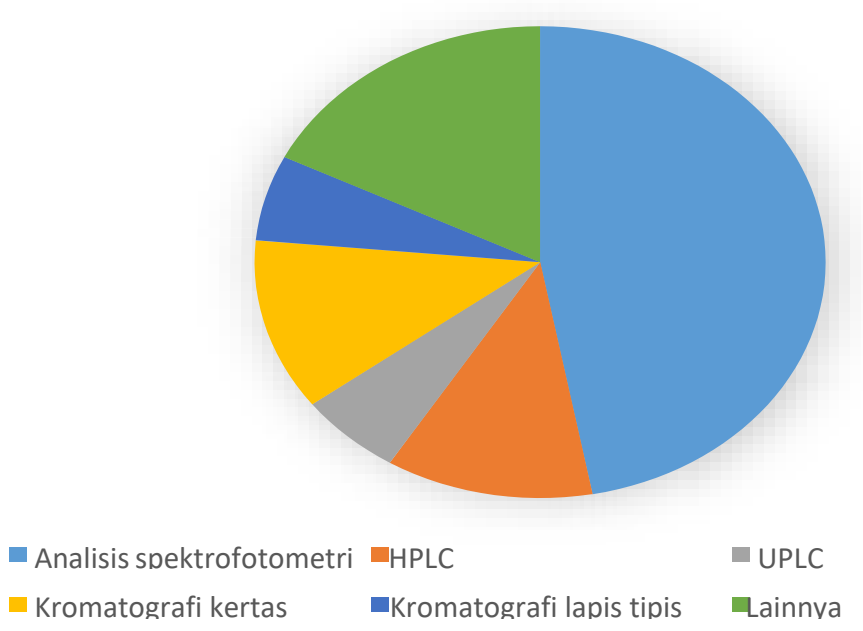

\section{PEMBAHASAN}

Penggunaan pewarna sintetik menjadi salah satu keuntungan bagi produsen baik makanan maupun kosmetik karena harganya yang terjangkau serta dapat membuat tampilan produk menjadi lebih menarik. Rhodamin B merupakan salah satu pewarna sintetik yang banyak digunakan sebagai pewarna pangan karena memiliki warna merah yang terang sehingga dapat menarik minat beli konsumen.

Berdasarkan hasil review yang diperoleh terlihat bahwa metode yang dominan digunakan adalah analisis menggunakan spektrofotometri yang dikombinasikan dengan detector UV-Vis. Alasan penggunaan metode spektrofotometri UV-Vis dilihat dari keunggulannya yaitu instrumennya yang sederhana dan tidak memerlukan keterampilan ahli. Namun, harus dipertimbangkan bahwa spektrum yang diperoleh dalam analisis sangat tergantung pada penyesuaian $\mathrm{pH}$ larutan, menggunakan asam atau alkali yang tepat. Penyesuaian pH larutan akan mempengaruhi panjang gelombang serapan maksimum, di mana pergeseran dan intensitas berdasarkan $\mathrm{pH}$ yang berbeda dapat diamati. Dalam larutan berair, $\mathrm{pH}$ memberikan efek mendalam pada kromofor terionisasi karena perbedaan tingkat konjugasi dalam kromofor terionisasi dan non-terionisasi (Moffat et al., 2011).

Selain spektrofotomerti HPLC yang dikombinasikan dengan detektor UV-Vis, fluoresensi maupun FID (Flame Ionization Detector) merupakan metode yang sering digunakan. Penggunaan metode HPLC dipilih karena memiliki beberapa kelebihan seperti sensitivitasnya yang tinggi, kolom dapat digunakan kembali, ideal untuk zat termolabil dan volatilitas rendah, mekanisme pemisahan lebih variatif, dan Penerapan luas untuk zat yang penting untuk industri, untuk banyak bidang sains, dan kepada publik (Skoog et al., 2007). Metode UPLC mengacu pada Ultra Liquid Liquid Chromatograph merupakan kategori lain dari ilmu pemisahan analitis yang bekerja pada prinsip-prinsip serupa HPLC dengan memperhatikan peningkatan kecepatan, sensitivitas dan resolusi (Desai et al., 2012). Kelebihan dari metode ini yaitu dapat menjaga kinerja resolusi, daya penyelesaian UPLC dapat dengan cepat mengkuantifikasi senyawa terkait dan tidak terkait, serta analisis yang lebih cepat melalui penggunaan 
bahan pemisahan baru dari partikel yang sangat halus. Namun karena adanya peningkatan tekanan sehingga memerlukan lebih banyak perawatan dan mengurangi umur kolom pada UPLC (Sheliya dan Shah, 2013).

Kromatografi lapis tipis (KLT) adalah bentuk kromatografi datar yang banyak digunakan untuk analisis kualitatif cepat. Analisis kuantitatif juga dimungkinkan, meskipun teknik ini paling banyak digunakan untuk skrining cepat, misalnya untuk memeriksa apakah terkandung senyawa yang diinginkan dalam sampel dan berapa banyak pengotor yang ada. Keunggulannya yaitu dapat digunakan untuk menganalisis beberapa sampel secara bersamaan namun pelarut yang digunakan untuk fase gerak harus memiliki kemurnian tinggi. Kehadiran sejumlah kecil air atau kotoran lain dapat menghasilkan kromatogram yang buruk (Christian, 2014). Metode kromatografi kertas pada umumnya sama dengan kromatografi lapis tipis yaitu dengan menggunakan fase diam dan fase gerak. Kertas umumnya berfungsi sebagai pendukung untuk fase diam cair. Fase gerak akan bergerak naik atau turun pada kertas (tergantung pada apakah pengembangan naik atau turun yang digunakan) dan memisahkan komponen sampel dalam proses (Ismail dan Nielsen, 2010). Metode lainnya yang dapat digunakan untuk mengidentifikasi Rhodamin B pada sampel yaitu dengan metode-metode konvensional seperti dengan reaksi warna ataupun dengan benang wol.

Test kit merupakan salah satu metode sederhana pemeriksaan Rhodamin B dengan cara mencelupkan test kit kedalam sampel dan hasilna bias langsung didapatkan. Sampel yang positif mengandung Rhodamin B akan menghasilkan larutan berwarna ungu. Kekurangan dari test kit yaitu perlu dilakukannya dua kali pencelupan untuk memastikan adanya kandungan Rhodamin B di dalam sampel, sehingga apabila terjadi kasus hasil dari kedua pencelupan berbeda dapat membuat rancu dan memberikan beberapa hipotesis. Metode wol dilakukan dengan mencelupkan benang wol kedalam sampel yang telah dilarutkan kemudian didiamkan sehingga zat warna dari sampel dapat menyerap. Keuntungan dari metode ini yaitu hasil residu dari larutan yang dapat dipekatkan dan digunakan sebagai sampel KLT. Kekurangan dari metode ini yaitu preparasi benang wol untuk menghilangkan kandungan lemak karena dikhawatirkan dapat mengganggu hasil analisis (Prasetya, 2016).

Setiap metode analisis memiliki kekurangan serta kelebihannya masing-masing, peneliti dapat memilih menggunakan metode apapun dalam menganalisis kandungan Rhodamin B pada makanan sesuai dengan ketersediaan bahan dan instrumennya.

\section{KESIMPULAN}

Analisis Rhodamin B pada makanan dan kosmetik dilakukan penting dilakukan karena, oleh karena itu perlu adanya pengembangan metode analitik sehingga dapat memberikan hasil yang akurat, tepat, sensitif, dan selektif untuk identifikasi senyawa tersebut. Terdapat beberapa metode analisis yang dapat digunakan untuk menganalisis sampel yang mengandung Rhodamin B. Metode yang paling banyak digunakan untuk menganalisis kandungan Rhodamin B yaitu metode spektrofotometri kemudian diikuti dengan HPLC dan metode-metode lainnya. 


\section{DAFTAR PUSTAKA}

Abdurrahmansyah, Fitraul A., dan Chrislia, D. Analisis Zat Pewarna Rhodamin B pada Saus Cabai yang Beredar di Kampus Universitas Islam Negeri Raden Fatah Palembang. Jurnal Biota. 2017;3(1): $38-42$.

Afriyeni dan Utari (2016). Identifikasi Zat Warna Rhodamin B pada Lipstik Berwarna Merah yang Beredar di Pasar Raya Padang. Jurnal Farmasi Higea, 8(1): 59-64.

Alesso, M., Bondioli, G., Talío, M. C., Luconi, M. O., dan Fernández, L. P. Micelles Mediated Separation Fluorimetric Methodology for Rhodamine B Determination in Condiments, Snacks and Candies. Food chemistry. 2012;134(1): 513-517.

Amir, N., \& Mahdi, C. (2017) Evaluasi Penggunaan Rhodamin B Pada Produk Terasi yang Dipasarkan Di Kota Makassar. Jurnal IPTEKS Pemanfaatan Sumberdaya Perikanan. 4(8): 128-133.

Bakheet, A. A. A. A., dan Zhu, X. S. Determination Of Rhodamine B Pigment in Food Samples by Ionic Liquid Coated Magnetic Core/Shell Fe 3 O 4@ Sio 2 Nanoparticles Coupled With Fluorescence Spectrophotometry. Science. 2017;5(1): 1-7.

BPOM RI. Badan Pengawas Obat dan Makanan Republik Indonesia. Rodamin B (Rhodamine B). Jakarta: BPOM. 2008

BPOM RI. Peraturan Kepala Badan Pengawas Obat Dan Makanan Republik Indonesia Nomor Hk.03.1.23.08.11.07331 Tahun 2011 Tentang Metode Analisis Kosmetika. Jakarta: Badan Pengawas Obat dan Makanan Republik Indonesia. 2011

BPOM RI. Penggunaan Rhodamin B pada Kosmetik. Jakarta: Badan Pengawas Obat dan Makanan Republik Indonesia. 2014

Duran, C., Ozdes, D., Bulut, V.N., Tüfekçi, M., Soylak, M. Cloud Point Extraction of Rhodamine 6G by Using Triton X-100 as Nonionic Surfactant. J. AOAC Int. 2011;94(1):286-292.

Febrina, G. R., Wiratmini, N. I., dan Sudatri, N. W. (2013). Pengaruh Pemberian Rhodamin B terhadap Siklus Estrus Mencit (Mus Musculus L.) Betina. Jurnal Biologi Udayana. 17(1).

Gresshma, R. L., \& Paul, M. R. Qualitative And Quantitative Detection Of Rhodamine B Extracted From Different Food Items Using Visible Spectrophotometry. Malaysian J. Forens. Sci,.2012;3:36-40.

Kemenkes RI. Farmakope Indonesia. Edisi V. Jakarta: Kementerian Kesehatan Republik Indonesia. 2014.

Laksmita A. S., Widayanti, N. P., dan Refi, M. A. F. (2018). Identifikasi rhodamin B dalamsaus sambal yang beredar di pasar tradisional dan modern Kota Denpasar. Jurnal Media Sains. 2(1).

Liu, X., Zhang, X., Zhou, Q., Bai, B., dan Ji, S. Spectrometric Determination Of Rhodamine B In Chili Powder After Molecularly Imprinted Solid Phase Extraction.Bulletin Of The Korean Chemical Society. 2013;34(11): 3381-3386.

Lu, Q., Gao, W., Du, J., Zhou, L., \& Lian, Y. Discovery Of Environmental Rhodamine B Contamination In Paprika During The Vegetation Process. Journal ofagricultural and food chemistry. 2012;60(19): 4773-4778.

Masyulani, F., dan Tristy, I. (2019). Identifikasi Zat Pewarna Rhodamin B Pada Lipstik Yang Beredar Di Kalangan Mahasiswi Fakultas Kedokteran Universitas Muhammadiyah Sumatera Utara Angkatan 2013. ANATOMICA MEDICAL JOURNAL| AMJ. 2(3): 117-124. 
Mayori, R., Marusin, N., dan Tjong, D. H. (2013). Pengaruh pemberian Rhodamin B terhadap struktur histologis ginjal mencit putih (Mus musculus L.). Jurnal Biologi Unand.2(1).

Peraturan Kepala Badan Pengawas Obat dan Makanan No. 36 tahun 2013 tentang Batas Maksimum Penggunaan. Bahan Tambahan Pangan Pengawet. Jakarta: BPOM. 2013

Peraturan Menteri Kesehatan No. 239/Menkes/Per/V/1985 tentang Zat Warna Tertentu yang Dinyatakan sebagai Bahan Berbahaya. Jakarta: Permenkes. 1985.

Prasetya, A. W. (2016). Deteksi Kandungan Rhodamin B Pada Saus Serta Cemaran Boraks Dan Bakteri Salmonella Sp. Pada Cilok Keliling Salatiga the Detection of Rhodamine B Content on the Sauce and the Contamination of Borax and Salmonella Sp. in the Cilok in Salatiga. Jurnal Ilmu Pertanian AGRIC. 28(1): 69-78.

Sidabutar, A. D., Nasution, A. N., Nasution, S. W., Nasution, S. L. R., Kurniawan, H. M., dan Girsang, E. (2019). Identifikasi dan Penetapan Kadar Rhodamin B dalam Kerupuk Berwarna Merah yang Beredar di Masyarakat. Jurnal Farmacia. 1(1): 24-30.

Soylak, M., Unsal, Y. E., Yilmaz, E., dan Tuzen, M. Determination Of Rhodamine B In Soft Drink, Waste Water And Lipstick Samples After Solid Phase Extraction. Food and chemical toxicology. 2011;49(8): 1796-1799.

Sun, D., and Yang, X. Rapid Determination Of Toxic Rhodamine B In Food Samples Using Exfoliated Graphene-Modified Electrode. Food analytical methods. 2017;10(6): 2046- 2052.

Syamsyuri, (2017). Analisis Kandungan Rhodamin B sebagai Pewarna pada Sediaan Lipstik Impor yang Beredar di Kota Makassar. Jurnal Farmasi UIN Alauddin Makassar. 5(1): 40-45.

Wang, W., Du, Y., Xiao, Z., Li, Y., dan Li, B. Rapid Qualitative Detection of Rhodamine B in Chili Oil by Deep Eutectic Solvent Extraction and a Microplate Reader. J Chromatogr Sep Tech. 2017;8(376): 2 .

Wibowo, B. A., dan Saebani, S. (2016). Pengaruh Rhodamine B Peroral Dosis Bertingkat Selama 12 Minggu Terhadap Gambaran Histopatologis Jantung Tikus Wistar. Jurnal Kedokteran Diponegoro. 5(2): 139-144.

WHO. World Health Organization.Obesity: preventing and managing the global epidemic Report of a WHO consultation on obesity; 1997 June 3-5; Geneva, Switzerland: WHO. 2000.

Yamlean, Paulina V. Y. (2011). Identifikasi dan Penetapan Kadar Rhodamin B pada Jajanan Kue Berwarna Merah Muda yang Beredar di Kota Manado. Jurnal Ilmiah Sains. 11(2): 289-295.

Yantih, Novi, Zulhemi A., A.D. Prasetya. Optimization and Validation of HPLC for the Analysis of Rhodamine-B in Sponge Cake. Proceedings of The 9th Joint Conference on Chemistry. 2014 November 12-13; Geand Candi Hotel. Semarang: UNNES Press; 2015 